\title{
PROSTAGLANDIN MODULATION OF N-FORMYLMETHIONYLLEUCYLPHENYLALANINE- INDUCED TRANSMEMBRANE POTENTIAL CHANGES IN RAT NEUTROPHILS
}

\author{
JOSEPH C. FANTONE, RICARDO E. DUQUE and SEM H. PHAN
}

Department of Pathology, University of Michigan Medical School, Ann Arbor, MI 48109 (U.S.A.)

(Received December 8th, 1983)

Key words: N-Formylmethionylleucylphenylalanine; Membrane potential; (Rat neutrophil)

Prostaglandins of the E-series (PGEs) and PGI 2 will inhibit formylmethionylleucylphenylalanine- (f-MetLeu-Phe) induced lysosomal enzyme release and superoxide-anion $\left(\mathrm{O}_{2}^{-}\right)$production by neutrophils. The inhibitory effects of PGEs and $\mathrm{PGI}_{2}$ on neutrophil functional responses have been correlated with their ability to increase intracellular cAMP. In this study we have examined the effects of PGEs and $\mathrm{PGI}_{2}$ on f-Met-Leu-Phe- and phorbol-myristate-acetate-induced rat neutrophil membrane potential changes using an optical probe of membrane potential 3,3-dipropylthiodicarbocyanine iodide. 15-( $S$ )-15-methyl-PGE 1 (15methyl-PGE $)_{1}$, a stable analogue of $\mathrm{PGE}_{1}$ and $\mathrm{PGI}_{2}$ inhibited f-Met-Leu-Phe-induced transmembrane potential changes in a dose-dependent manner. This inhibition was correlated with the ability of these agents to increase intracellular cAMP levels and inhibit $\mathrm{O}_{2}^{-}$production and degranulation. In contrast, 15-methyl$P_{1} E_{1}$ and $P_{2} I_{2}$, did not inhibit phorbol-myristate-acetate-induced transmembrane potential changes and $\mathrm{O}_{2}^{-}$production. These results suggest independent mechanisms of activation of neutrophils by phorbol myristate acetate and f-Met-Leu-Phe, and they also suggest that the inhibitory effects of prostaglandins and cAMP on f-Met-Leu-Phe-stimulated cells is at a step or steps prior to activation of those processes involved in effecting changes in transmembrane potential, which are common to both stimuli.

\section{Introduction}

Stimulation of certain neutrophil functions by f-Met-Leu-Phe is initiated by its binding to a specific formyl peptide receptor on the plasma membrane. One of the early events following the binding of $\mathrm{f}-\mathrm{Met}$-Leu-Phe to its receptor is a change in sodium, potassium and calcium ion fluxes across the plasma membrane, associated with a change in the transmembrane potential. These events have been shown to precede the release of superoxide

Abbreviations: f-Met-Leu-Phe, $N$-formylmethionylleucylphenylalanine; $\Delta F$, relative fluorescence change; TPCK, tosylL-phenylalanylchloromethyl ketone; $\operatorname{di}(S)-C_{3}-(5), 3,3^{\prime}$-dipropylthiodicarbocyanine iodide; $\mathrm{PGE}_{1}$, prostaglandin $\mathrm{E}_{1} ; 15$ methyl-PGE $\mathrm{P}_{1}, 15-(S)$-15-methyl-prostaglandin $\mathrm{E}_{1} ; \mathrm{PGI}_{2}$, prostaglandin $\mathrm{I}_{2} ; \mathrm{PGF}_{2 \alpha}$, prostaglandin $\mathrm{F}_{2 \alpha}$. anion and lysosomal degranulation. A high degree of correlation of stimulus-induced changes in transmembrane potential with the production of $\mathrm{O}_{2}^{-}$and degranulation has been demonstrated [1-3].

Prostaglandins of the E series (PGEs) and $\mathrm{PGI}_{2}$ have been shown to inhibit" neutrophil-dependant inflammatory reactions in vivo. Systemic treatment of rats with $\mathrm{PGE}_{1}$ will inhibit immune complex-induced vasculitis in the skin [4], carrageenin-induced inflammation in the rat footpad [5] and adjuvant arthritis [6]. In addition, pretreatment of neutrophils with PGEs or $\mathrm{PGI}_{2}$ has been shown to inhibit neutrophil chemotaxis [7], aggregation [8] $\mathrm{O}_{2}^{-}$production [9-11] and degranulation [12].

The inhibition of neutrophil stimulation by $\mathrm{f}$ - 
Met-Leu-Phe is thought to be mediated by increases in intracellular cAMP levels induced by PGEs and $\mathrm{PGI}_{2}$. Studies performed using mast cells and basophil leukemia cells lines have correlated the inhibition effects of prostaglandins and cAMP on calcium release and degranulation with their ability to inhibit cell membrane-associated phospholipid transmethylation reactions [13]. Additional studies suggest that the inhibitory effects of $\mathrm{PGE}_{1}, \mathrm{PGI}_{2}$ and cAMP on platelet aggregation are secondary to their ability to decrease intracellular free-calcium levels after stimulation $[14,15]$.

In an effort to clarify the mechanisms by which PGEs and $\mathrm{PGI}_{2}$ modify neutrophil stimulation, we have investigated the effects of these agents on the transmembrane potential change associated with f-Met-Leu-Phe stimulation of rat neutrophils. We have found that PGEs, $\mathrm{PGI}_{2}$ and other agents which increase intracellular cAMP levels inhibit f-Met-Leu-Phe-induced transmembrane potential changes at concentrations which also inhibit superoxide-anion production and degranulation. The data indicate that these agents can alter an early biophysical response of rat neutrophil plasma membrane to f-Met-Leu-Phe stimulation, and further suggest that this effect may be mediated by increases in intracellular cAMP levels.

\section{Materials and Methods}

Animals and chemicals. Adult female Long Evans rats, weighing approx. $400 \mathrm{~g}$, were used throughout this study. All chemicals were purchased from Sigma (St. Louis, MO), unless otherwise noted. Prostaglandins, including 15-( $S)$ 15-methyl-PGE , $_{1}$ were kindly provided by Dr. John Pike of the Upjohn Co. (Kalamazoo, MI). The cyanine dye 3,3'-dipropylthiodicarbocyanine ( $\left.\mathrm{di}(\mathrm{S})-\mathrm{C}_{3}-(5)\right)$ was obtained from Molecular Probes Incorporated (Junction City, OR). Prostaglandins were prepared as stock solutions in ethanol (10 $\mathrm{mg} / \mathrm{ml})$. Cytochalasin B $(5 \mathrm{mg} / \mathrm{ml})$, and $N$-formylmethionylleucylphenylalanine were prepared and stored as $1 \cdot 10^{-2} \mathrm{M}$ tock solutions in dimethylsulfoxide at $-20^{\circ} \mathrm{C}$.

Preparation of neutrophils and enzyme and $\mathrm{O}_{2}^{-}$ assays. Cells were suspended in a balanced salt solution consisting of $138 \mathrm{mM} \mathrm{NaCl} / 5.4 \mathrm{mM}$ $\mathrm{KCl} / 1.6 \mathrm{mM} \mathrm{CaCl}_{2} / 0.8 \mathrm{mM} \mathrm{MgSO}_{4} / 0.8 \mathrm{mM}$
$\mathrm{Na}_{2} \mathrm{HPO}_{4} / 0.8 \mathrm{mM} \overline{\mathrm{K}} \mathrm{H}_{2} \mathrm{PO}_{4} / 10 \mathrm{mM}$ Hepes $(\mathrm{pH}$ 7.4). Neutrophils were obtained from rat peritoneal cavities approx. $16 \mathrm{~h}$ after injection of $50 \mathrm{ml}$ of $1.0 \%$ oyster glycogen in $0.9 \%$ of saline, as previously described [16]. Lysosomal enzyme release was performed by incubating $2 \cdot 10^{6}$ cells in the presence of $5 \mu \mathrm{g} / \mathrm{ml}$ cytochalasin B at varying concentrations of $\mathrm{f}$-Met-Leu-Phe in a total volume of $250 \mu \mathrm{l}$ for $10 \mathrm{~min}$ at $37^{\circ} \mathrm{C}$. Reactions were terminated by placing the tubes in an ice-bath followed by centrifugation. $N$-Acetyl- $\beta$-D-glucosaminidase, lysozyme and lactate dehydrogenase activities were assayed in the supernatant, as previously described [17,18]. All assays were performed in triplicate, and the data are expressed as percentage of maximum (as assessed by using $0.1 \%$ Triton X-100 to lyse cells completely) enzyme release $( \pm$ S.E.). The amount of superoxide anion produced was determined by the superoxide dismutase-inhibitable reduction of ferricytochrome $c$ by stimulated cells, as previously described [9], and the results are expressed as nmol $\mathrm{O}_{2}^{-} / 10^{6}$ cells per $10 \mathrm{~min}$, using an extinction coefficient of $21.2 \mathrm{~cm}^{-1} \cdot \mathrm{mM}^{-1}$ at $550 \mathrm{~nm}$. All assays were performed in triplicate and data are expressed as mean values \pm S.E.

Measurement of membrane potential changes. Membrane potential changes were measured as previously described [3]. Briefly, neutrophils (2 . $10^{6} \mathrm{cells} / \mathrm{ml}$ ) were exposed to $2 \cdot 10^{-6} \mathrm{M}$ diS- $\mathrm{C}_{3}-(5)$ at $37^{\circ} \mathrm{C}$ with constant stirring of the cell suspension, until (usually after less than $5 \mathrm{~min}$ ) there was no change in the fluorescence intensity as measured using a Varian SF330 spectrofluorimeter. The cells were then stimulated with various concentrations of f-Met-Leu-Phe or phorbol myristate acetate, and the maximum change in fluorescence (excitation at $622 \mathrm{~nm}$, emission as $655 \mathrm{~nm}$ and band widths of $10 \mathrm{~nm}$ ) was determined. The resting membrane potential was determined using the 'null point' method as described previously [3]. Membrane potential changes were expressed as the maximum change in fluorescence $(\Delta F)$.

Measurement of cAMP levels. $1.0 \mathrm{ml}$ of rat neutrophils $\left(5 \cdot 10^{6}\right.$ cells $\left./ \mathrm{ml}\right)$ were incubated in the presence or absence of prostaglandins for $5 \mathrm{~min}$ at $37^{\circ} \mathrm{C}$. The reaction was stopped by the addition of trichloroacetic acid, to a final concentration of $6 \%$. The supernates obtained after centrifugation 
$(2000 \times g$ for $50 \mathrm{~min})$ were extracted three times with diethylether $(1.0 \mathrm{ml}$ vol.) to remove trichloroacetic acid. The aqueous phase was then evaporated to dryness. The dried samples were then resuspended in $0.05 \mathrm{M}$ sodium acetate ( $\mathrm{pH}$ 6.2), and cAMP levels were determined by radioimmunoassay (New England Nuclear, Boston MA).

Statistical analysis. Student's $t$-test (two-tailed analysis) was used to compare the mean values of the responses of treated cells with those for nontreated control cells. $P$ values less than 0.05 were considered statistically significant.

\section{Results}

Effects of prostaglandins on f-Met-Leu-Phe-induced transmembrane potential changes

The effect of 15-methyl-PGE 1 , a stable analogue of $\mathrm{PGE}_{1}$ [4], on f-Met-Leu-Phe-induced changes in $\Delta F$ of rat neutrophils incubated with $\operatorname{di}(\mathrm{S})-\mathrm{C}_{3}-(5)$ was examined. 15-methyl-PGE $\mathrm{PG}_{1}$ inhibited f-Met-Leu-Phe-induced transmembrane potential changes in a dose-dependent manner

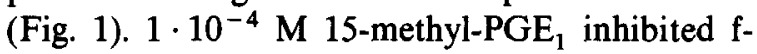
Met-Leu-Phe-induced $\Delta F$ by more than $60 \%$ over a broad range of concentrations of stimulus. 1 . $10^{-5}$ M 15-methyl-PGE 1 was much less effective in inhibiting $\mathrm{f}$-Met-Leu-Phe-induced $\Delta F$ at each

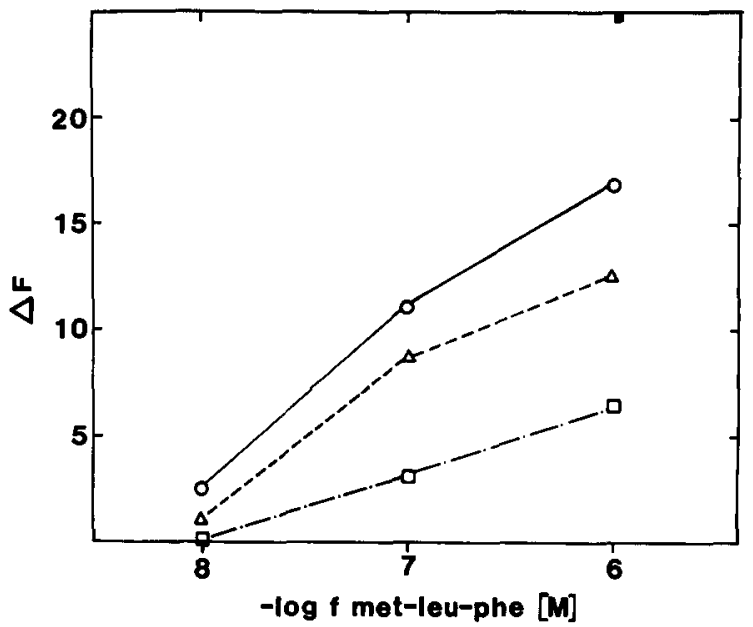

Fig. 1. Inhibition of f-Met-Leu-Phe-induced transmembrane potential changes. $2 \cdot 10^{6}$ neutrophils $/ \mathrm{ml}$ were equilibrated with $\operatorname{di}(S)-C_{3}-(5)(2 \mu \mathrm{M}$, final concentration). Varying doses of f-Met-Leu-Phe were added to cells pretreated for $5 \mathrm{~min}$ at $37^{\circ} \mathrm{C}$ with; ethanol $(0.1 \%$, final concentration), $(\mathrm{O}-\ldots \mathrm{O})$, 15-methyl-PGE $1\left(10^{-5} \mathrm{M}\right),(\Delta--\Delta)$, and 15-methyl-PGE 1 . $\left.10^{-4} \mathrm{M}\right),(\square--\square)$. Results are duplicate determinations with variations smaller than $10 \%$.

concentration of stimulus. Increasing concentrations of f-Met-Leu-Phe failed to overcome totally the inhibitory effects of $15-$ methyl-PGE $_{1}$, even at concentrations of stimulus as high as $1 \cdot 10^{-6} \mathrm{M}$. The inhibition of the f-Met-Leu-Phe-induced

\section{TABLE I}

EFFECT OF PROSTAGLANDINS ON f-Met-Leu-Phe-INDUCED CHANGES IN FLUORESCENCE OF diS-C ${ }_{3}$-(5)-TREATED RAT NEUTROPHILS.

Rat polymorphonuclear neutrophils were equilibrated with diS- $\mathrm{C}_{3}-(5)$ prior to pre-treatment with each reagent $\left(37^{\circ} \mathrm{C}, 5 \mathrm{~min}\right.$.). Cells were stimulated with $\mathrm{f}-\mathrm{Met}$-Leu-Phe, and the maximum change in fluorescent intensity $(\Delta F)$ was determined. $\Delta F$ values represent means \pm S.E. Each experiment shown is a representative example from at least three separate experiments. n.s., not significant.

\begin{tabular}{|c|c|c|c|}
\hline Treatment & $\Delta F$ & $\mathscr{0}$ inhibition & $P$ value \\
\hline $\begin{array}{l}\text { f-Met-Leu-Phe }\left(1 \cdot 10^{-6} \mathrm{M}\right) \\
\text { f-Met-Leu-Phe }+15-\text { methyl-PGE }_{1}\left(1 \cdot 10^{-5} \mathrm{M}\right) \\
\text { f-Met-Leu-Phe }+\mathrm{PGI}_{2}\left(1 \cdot 10^{-5} \mathrm{M}\right) \\
\text { f-Met-Leu-Phe }+\mathrm{PGF}_{2 \alpha} \\
\left(1 \cdot 10^{-5} \mathrm{M}\right)\end{array}$ & $\begin{array}{l}19.8 \pm 1.6 \\
11.2 \pm 0.2 \\
12.2 \pm 1.9\end{array}$ & $\begin{array}{l}- \\
43.3 \\
38.1\end{array}$ & $\begin{array}{l}- \\
<0.01 \\
<0.05\end{array}$ \\
\hline $\begin{array}{l}\text { f-Met-Leu-Phe }\left(1 \cdot 10^{-7} \mathrm{M}\right) \\
\text { f-Met-Leu-Phe }+15-\text { methyl- } \\
-\operatorname{PGE}_{1}\left(3 \cdot 10^{-5} \mathrm{M}\right)\end{array}$ & $26.0 \pm 1.2$ & 43.1 & $<0.001$ \\
\hline $\begin{array}{l}\text { f-Met-Leu-Phe + dibutyryl } \\
\text { cAMP }\left(1 \cdot 10^{-3} \mathrm{M}\right)\end{array}$ & $14.5 \pm 2.0$ & 44.2 & $<0.001$ \\
\hline $\begin{array}{l}\text { f-Met-Leu-Phe }+ \\
\text { isoproterenol }\left(5 \cdot 10^{-6} \mathrm{M}\right)+ \\
\text { theophylline }\left(5 \cdot 10^{-4} \mathrm{M}\right)\end{array}$ & $15.7 \pm 0.9$ & 39.6 & $<0.001$ \\
\hline
\end{tabular}




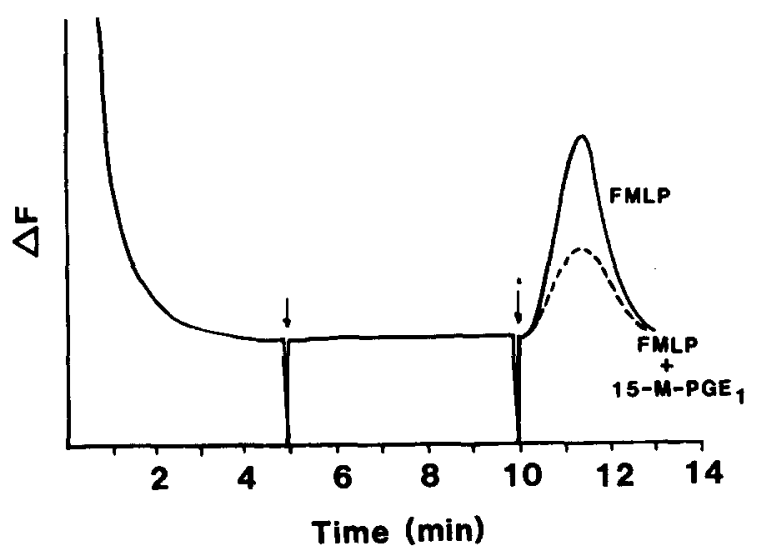

Fig. 2. Effect of 15-methyl-PGE 1 on f-Met-Leu-Phe-induced $\operatorname{di}(\mathrm{S})-\mathrm{C}_{3}-(5)$ fluorescence. $2 \cdot 10^{6}$ neutrophils $/ \mathrm{ml}$ were equilibrated with $\operatorname{di}(S)-C_{3}-(5)(2 \mu \mathrm{M}$, final concentration). Cells were pre-treated $(\downarrow)$ with either ethanol $(0.1 \%$ final concentration) (-) or 15-methyl-PGE 1 (10 $\mu \mathrm{M}$, final concentration) (.....) for $5 \mathrm{~min}$ at $37^{\circ} \mathrm{C}$ prior to stimulation with $\mathrm{f}$-Met-Leu-Phe $\left(1 \cdot 10^{-7} \mathrm{M}\right.$, final concentration). The second arrow indicates addition of f-Met-Leu-Phe (FMLP).

transmembrane potential change by 15 -methyl$\mathrm{PGE}_{1}$ demonstrated a molecular class specificity, since $\mathrm{PGI}_{2}$, but not $\mathrm{PGF}_{2 a}$, also inhibited f-MetLeu-Phe-induced fluorescence changes (Table I). Although 15-methyl-PGE ${ }_{1}$ pretreatment of rat neutrophils decreased the maximum f-Met-LeuPhe-induced transmembrane potential change, it did not alter the lag time to achieve maximal fluorescence (Fig. 2).After a $5 \mathrm{~min}$ preincubation of rat neutrophils with 15 -methyl-PGE $1\left(1 \cdot 10^{-5}\right.$ $\mathrm{M})$, the fluorescence change with f-Met-Leu-Phe occurred rapidly, reaching a maximum within $60 \mathrm{~s}$, followed by a gradual decrease in fluorescence.

Pre-treatment of rat neutrophils with 15methyl-PGE ${ }_{1}$ did not significantly alter the baseline fluorescence of $\mathrm{di}(\mathrm{S})-\mathrm{C}_{3}-(5)$ or the resting membrane potential. The resting membrane potential of rat neutrophils in the absence of prostaglandins was calculated to be $-60.2 \mathrm{mV}$, while in the presence of 15 -methyl-PGE $1,\left(1 \cdot 10^{-4} \mathrm{M}\right)$ the resting membrane potential was $-58.0 \mathrm{mV}$. Both of these values are consistent with previously published values $[19,20]$ and were not significantly different.

The inhibitory effect of 15 -methyl-PGE 1 on f-Met-Leu-Phe-induced transmembrane potential changes was reversible. Neutrophils which had been washed (twice) with buffered salt solution (see Materials and Methods) at $4^{\circ} \mathrm{C}$ and incubated at $37^{\circ} \mathrm{C}$ for $10 \mathrm{~min}$ after pre-incubation with 15 -methyl-PGE $\left(1 \cdot 10^{-5} \mathrm{M}\right)$ showed no inhibition of f-Met-Leu-Phe-induced transmembrane potential changes (data not shown) and $\mathrm{O}_{2}^{-}$production [9]. In addition, pre-incubation periods of $30 \mathrm{~s}$ with $15-$ methyl-PGE 1 produced reproducible and significant inhibition of f-Met-Leu-Phe-induced transmembrane potential changes and $\mathrm{O}_{2}^{-}$ production (data not shown). This correlates with the rapid increase in intracellular cAMP levels associated with $\mathrm{PGE}_{1}$ and $\mathrm{PGI}_{2}$ exposure of neutrophils [7,12].

\section{Effect of dibutyryl cAMP and isoproterenol on $f$ - Met-Leu-Phe-induced transmembrane potential changes}

Since the inhibitory effects of PGEs and $\mathrm{PGI}_{2}$ on neutrophil functional responses are thought to be mediated by activation of adenylate cyclase and increased intracellular cAMP levels, the effects of other agents known to elevate cAMP levels on f-Met-Leu-Phe-induced fluorescence changes were determined. Both dibutyryl cAMP and isoproterenol in the presence of theophylline inhibited f-Met-Leu-Phe-induced fluorescence changes in a dose-dependent manner (Table I). Preincubation of rat neutrophils with dibutyryl cAMP at a concentration of $1 \cdot 10^{-3} \mathrm{M}$ inhibited f-Met-Leu-Pheinduced changes in transmembrane potential by $44.2 \%$. At concentrations of dibutyryl cAMP less than $1 \cdot 10^{-4} \mathrm{M}$ no inhibition of transmembrane potential changes was observed (data not shown). Isoproterenol $\left(5 \cdot 10^{-6} \mathrm{M}\right)$ in the presence of theophylline $\left(5 \cdot 10^{-4} \mathrm{M}\right)$ (concentrations previously shown to produce significant increases in neutrophil intracellular cAMP levels $[7,12])$, produced a similar degree of inhibition (39.6\%) of f-MetLeu-Phe-induced transmembrane potential changes. However, in the absence of theophylline or at concentrations of isoproterenol less then $1 \cdot 10^{-6} \mathrm{M}$, minimal inhibition of transmembrane potential changes was observed.

Correlation of inhibition effects of prostaglandins on transmembrane potential changes with functional responses

The dose-dependent inhibitory effect on f-Met- 


\section{TABLE II}

\section{EFFECT OF PROSTAGLANDINS ON PHORBOL-MYRISTATE-ACETATE-INDUCED CHANGES IN FLUORESCENCE OF di(S)-C C $_{3}$ (5)-TREATED RAT NEUTROPHILS}

Rat polymorphonuclear neutrophils were treated as described in Table I. Cells were stimulated with phorbol myristate acetate, and the maximum change in fluorescent intensity $(\Delta F)$ was determined. $\Delta F$ values represent means $\pm S$.E. Each experiment shown is a representative example from at least three separate experiments. n.s., not significant.

\begin{tabular}{|c|c|c|c|}
\hline Treatment & $\Delta F$ & \% inhibition & $P$ value \\
\hline \multicolumn{4}{|l|}{ Phorbol myristate acetate } \\
\hline$(100 \mathrm{ng} / \mathrm{ml})$ & $16.6 \pm 0.2$ & - & - \\
\hline \multicolumn{4}{|l|}{ Phorbol myristate acetate + } \\
\hline 15-methyl-PGE $\left(1.2 \cdot 10^{-4} \mathrm{M}\right)$ & $16.0 \pm 0.6$ & 3.6 & n.s. \\
\hline \multicolumn{4}{|l|}{ Phorbol myristate acetate +} \\
\hline 15-methyl-PGE $1\left(6 \cdot 10^{-5} \mathrm{M}\right)$ & $15.7 \pm 1.4$ & 5.4 & n.s. \\
\hline f-Met-Leu-Phe $\left(1 \cdot 10^{-5} \mathrm{M}\right)$ & $16.5 \pm 0.3$ & - & - \\
\hline \multicolumn{4}{|l|}{ f-Met-Leu-Phe + } \\
\hline 15 -methyl-PGE $1\left(6 \cdot 10^{-5} \mathrm{M}\right)$ & $10.7 \pm 0.9$ & 35.2 & $<0.001$ \\
\hline \multicolumn{4}{|l|}{ Phorbol myristate acetate } \\
\hline$(100 \mathrm{ng} / \mathrm{ml})$ & $19.2 \pm 1.3$ & - & - \\
\hline \multicolumn{4}{|l|}{ Phorbol myristate acetate +} \\
\hline 15-methyl-PGE $1\left(1 \cdot 10^{-5} \mathrm{M}\right)$ & $20.2 \pm 1.3$ & -1.1 & n.s. \\
\hline \multicolumn{4}{|l|}{ Phorbol myristate acetate } \\
\hline$(10 \mathrm{ng} / \mathrm{ml})$ & $17.2 \pm 0.6$ & - & - \\
\hline \multicolumn{4}{|l|}{ Phorbol myristate acetate + } \\
\hline 15-methyl-PGE $1\left(1 \cdot 10^{-5} \mathrm{M}\right)$ & $16.7 \pm 0.3$ & 2.9 & n.s. \\
\hline f-Met-Leu-Phe $\left(1 \cdot 10^{-6} \mathrm{M}\right)$ & $30.0 \pm 1.2$ & - & - \\
\hline \multicolumn{4}{|l|}{ f-Met-Leu-Phe + 15-methyl- } \\
\hline $\operatorname{PGE}_{1}\left(1 \cdot 10^{-5} \mathrm{M}\right)$ & $20.3 \pm 1.2$ & 32.6 & $<0.01$ \\
\hline
\end{tabular}

TABLE III

EFFECT OF PRE-TREATMENT OF RAT NEUTROPHILS WITH 15-METHYL-PGE ${ }_{1}$, PGI $_{2}$, PGF $_{2 \alpha}$, DIBUTYRYL cAMP AND DIBUTYRYL CGMP ON $\mathrm{O}_{2}^{-}$SECRETION AND LYSOSOMAL ENZYME RELEASE

Rat polymorphonuclear neutrophils were pre-incubated with the prostaglandins or cyclic nucleotides for 5 min $\left(37^{\circ} \mathrm{C}\right)$ prior to stimulation with f-Met-Leu-Phe. the production of $\mathrm{O}_{2}^{-}$and secretion of $N$-acetyl- $\beta$-D-glucosaminidase were determined. $\mathrm{O}_{2}^{-}$secretion and enzyme release are expressed as the mean \pm S.E. n.s., not significant.

\begin{tabular}{|c|c|c|c|c|c|c|}
\hline Treatment & $\mathrm{O}_{2}^{-}\left(\mathrm{nmol} / 2 \cdot 10^{6}\right.$ cells $)$ & \% inhibition & $P$ value & $\begin{array}{l}N \text {-Acetyl- } \beta-O- \\
\text { glucosaminidase } \\
\text { \% maximum enzyme }\end{array}$ & $\%$ inhibition & $P$ value \\
\hline $\begin{array}{l}\text { f-Met-Leu-Phe }\left(1 \cdot 10^{-6} \mathrm{M}\right) \\
\text { f-Met-Leu-Phe + }\end{array}$ & $5.9 \pm 0.2$ & - & - & $1 A .7 \pm 0.5$ & - & - \\
\hline $\begin{array}{l}\text { 15-methyl-PGE }\left(1 \cdot 10^{-4} \mathrm{M}\right) \\
\text { f-Met-Leu-Phe+ }\end{array}$ & $2.6 \pm 0.2$ & 55.9 & $<0.01$ & $8.3 \pm 0.3$ & 43.5 & $<0.02$ \\
\hline $\begin{array}{l}\text { 15-methyl-PGE }\left(1 \cdot 10^{-5} \mathrm{M}\right) \\
\text { f-Met-Leu-Phe+ }\end{array}$ & $3.3 \pm 0.4$ & 44.1 & $<0.05$ & $11.2 \pm 0.3$ & 23.8 & $<0.05$ \\
\hline $\begin{array}{l}\mathrm{PGI}_{2}\left(1 \cdot 10^{-4} \mathrm{M}\right) \\
\text { f-Met-Leu-Phe }+\end{array}$ & $2.5 \pm 0.1$ & 57.6 & $<0.01$ & $9.2 \pm 0.2$ & 37.4 & $<0.01$ \\
\hline $\begin{array}{l}\mathrm{PGI}_{2}\left(1 \cdot 10^{-5} \mathrm{M}\right) \\
\text { f-Met-Leu-Phe }+\end{array}$ & $3.7 \pm 0.1$ & 37.2 & $<0.02$ & $12.3 \pm 0.1$ & 16.3 & $<0.05$ \\
\hline $\begin{array}{l}\text { PGF }_{2 \alpha}\left(1 \cdot 10^{-5} \mathrm{M}\right) \\
\text { f-Met-Leu-Phe }+\end{array}$ & $5.5 \pm 0.2$ & 6.8 & n.s. & $14.2 \pm 0.2$ & 3.4 & n.s. \\
\hline $\begin{array}{l}\text { dibutyryl cAMP }\left(1 \cdot 10^{-3} \mathbf{M}\right) \\
\text { f-Met-Leu-Phe }+\end{array}$ & $3.2 \pm 0.1$ & 45.7 & $<0.02$ & $11.8 \pm 0.4$ & 19.7 & $<0.05$ \\
\hline dibutyryl cGMP $\left(1 \cdot 10^{-3} \mathrm{M}\right)$ & $5.9 \pm 0.2$ & 0.0 & n.s. & $15.0 \pm 0.3$ & 2.0 & n.s. \\
\hline
\end{tabular}


TABLE IV

EFFECT OF PRE-TREATMENT OF RAT NEUTROPHILS WITH 15-METHYL-PGE ${ }_{1}$ ON PHORBOL-MYRISTATEACETATE-INDUCED $\mathrm{O}_{2}^{-}$SECRETION.

Rat neutrophils $\left(2 \cdot 10^{6}\right.$ cells $)$ were pre-incubated in the presence or absence of 15 -methyl-PGE $\left(1 \cdot 10^{-4} \mathrm{M}\right)$ at $\left(37^{\circ} \mathrm{C}, 5 \mathrm{~min}\right)$ and then stimulated with either phorbol myristate acetate of $\mathrm{f}-\mathrm{Met}$-Leu-Phe and incubated for an additional $10 \mathrm{~min}$ at $37^{\circ} \mathrm{C}$. The number of $\mathrm{nmol}$ of $\mathrm{O}_{2}^{-}$produced was determined (see Materials and Methods). Values represent means \pm S.E. Each experiment shown is a representative example from at least three separated experiments. HBSS, Hanks' balanced salt solution; n.s., not significant.

\begin{tabular}{|c|c|c|c|}
\hline Treatment & $\begin{array}{l}\mathrm{O}_{2}^{--}\left(\mathrm{nmol} / 2 \cdot 10^{6}\right. \\
\text { cells })\end{array}$ & $\%$ inhibition & $P$ value \\
\hline HBSS & $3.0 \pm 0.4$ & - & - \\
\hline $\begin{array}{l}\text { Phorbol myristate acetate } \\
\qquad(100 \mathrm{ng} / \mathrm{ml}) \\
(10 \mathrm{ng} / \mathrm{ml}) \\
(1 \mathrm{ng} / \mathrm{ml})\end{array}$ & $\begin{array}{r}44.7 \pm 0.3 \\
39.6 \pm 1.0 \\
4.3 \pm 0.3\end{array}$ & $\begin{array}{l}- \\
-\end{array}$ & $\begin{array}{l}- \\
- \\
-\end{array}$ \\
\hline $\begin{array}{l}\text { Phorbol myristate acetate } \\
\qquad(100 \mathrm{ng} / \mathrm{ml})+15 \text {-methyl-PGE } \\
1\left(1 \cdot 10^{-4} \mathrm{M}\right) \\
\left(10 \mathrm{ng} / \mathrm{ml}+15-\text { methyl-PGE }_{1}\left(1 \cdot 10^{-4} \mathrm{M}\right)\right. \\
\left(1 \mathrm{ng} / \mathrm{ml}+15 \text {-methyl-PGE } 1\left(1 \cdot 10^{-4} \mathrm{M}\right)\right.\end{array}$ & $\begin{array}{r}49.3 \pm 1.6 \\
41.9 \pm 0.9 \\
4.5 \pm 0.1\end{array}$ & $\begin{array}{r}-10.3 \\
-5.8 \\
-4.6\end{array}$ & $\begin{array}{l}\text { n.s. } \\
\text { n.s. } \\
\text { n.s. }\end{array}$ \\
\hline $\begin{array}{l}\text { HBSS + 15-methyl-PGE }\left(1 \cdot 10^{-4} \mathrm{M}\right) \\
\text { f-Met-Leu-Phe }\left(1 \cdot 10^{-6} \mathrm{M}\right) \\
\text { f-Met-Leu-Phe }\left(1 \cdot 10^{-4} \mathrm{M}\right)\end{array}$ & $\begin{array}{l}2.7 \pm 1.4 \\
5.7 \pm 0.1 \\
3.1 \pm 0.2\end{array}$ & $\begin{array}{c}10.0 \\
- \\
45.6\end{array}$ & $\begin{array}{l}\text { n.s. } \\
\bar{P}<0.01\end{array}$ \\
\hline
\end{tabular}

Leu-Phe-induced fluorescence changes by 15methyl-PGE 1 and $\mathrm{PGI}_{2}$ correlated with their inhibitory effects on f-Met-Leu-Phe-induced superoxide anion production and lysosomal enzyme release (Table III). Concentrations of 15-methyl$\mathrm{PGE}_{1}$ and $\mathrm{PGI}_{2}$ greater than $1 \cdot 10^{-5} \mathrm{M}$ and dibutyryl cAMP $\left(1 \cdot 10^{-3} \mathrm{M}\right)$ consistently inhibited f-Met-Leu-Phe-induced transmembrane potential changes and $\mathrm{O}_{2}^{-}$production by approx. $40 \%$. However, these agents appeared to be less effective in inhibiting $\mathrm{f}$-Met-Leu-Phe-induced lysosomal enzyme release. Although 15-methyl-PGE ${ }_{1}$ and $\mathrm{PGI}_{2}$ at relatively high concentrations $\left(1 \cdot 10^{-4} \mathrm{M}\right)$ inhibited $N$-acetyl- $\beta$-D-glucosaminidase release to relatively the same degree as $\mathrm{O}_{2}^{-}$and transmembrane potential changes, at $1 \cdot 10^{-5} \mathrm{M}$ there was only an approx. $20 \%$ inhibition of enzyme release compared to a $40 \%$ inhibition of $\mathrm{O}_{2}^{-}$production and transmembrane potential change. A similar differential effect of dibuturyl cAMP on the functional response of rat neutrophils was observed. Dibutyryl cAMP at $1 \cdot 10^{-3} \mathrm{M}$ inhibited lysosomal enzyme release by $19.7 \%$, compared to a $45.7 \%$ inhibition of $\mathrm{O}_{2}^{-}$production. In contrast, neither PGF $_{2 \alpha}$ nor dibutyryl cGMP altered either the functional responses of the cells to f-Met-Leu-Phe or the f-Met-Leu-Phe-induced membrane potential changes. These data suggest a close correlation between changes in transmembrane potential and $\mathrm{O}_{2}^{-}$production and a partial dissociation between these two indices of neutrophil stimulation and degranulation.

\section{Effects of prostaglandins on cAMp levels}

The ability of 15 -methyl-PGE 1 to increase rat neutrophil intracellular cAMP levels was verified and was dose-dependent. At a concentration of

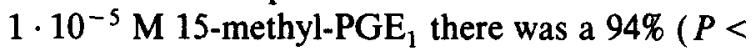
0.001 ) increase in intracellular cAMP levels (Table $\mathrm{V})$. This is a similar dose range in which consistent inhibition of f-Met-Leu-Phe-induced changes of both fluorescence and functional responses were observed. However, at concentrations of 15 methyl-PGE $\mathrm{P}_{1}$ of $1 \cdot 10^{-6} \mathrm{M}$ or theophylline of 5 . $10^{-4} \mathrm{M}$, there was no consistent inhibition of either the f-Met-Leu-Phe-induced changes in transmembrane potential or functional responses, despite a 20-30\% increase in intracellular cAMP levels. These observations suggest that significant elevations of intracellular cAMP levels of approx. $100 \%$ above baseline levels are necessary for significant inhibition of f-Met-Leu-Phe-induced responses of glycogen elicited rat neutrophils. 
TABLE V

EFFECT OF PROSTAGLANDIN $E_{1}$ AND THEOPHYLLINE ON INTRACELLULAR cAMP LEVELS OF RAT NEUTROPHILS

$0.5 \mathrm{ml}$ of rat polymorphonuclear neutrophils $\left(1 \cdot 10^{7}\right.$ cells $\left./ \mathrm{ml}\right)$ were pre-incubated at $37^{\circ} \mathrm{C}$ for 5 min. in the presence or absence of 15 -methyl-PGE 1 or theophylline. The reactions were terminated by the addition of trichloroacetic acid (final concentration $6 \%$ ), and the concentrations of cAMP were determined. All assays were performed in triplicate and Student's $i$-test was used to compare treated with nontreated cells. Each experiment shown is a representative example from at least three separate experiments.

\begin{tabular}{|c|c|c|c|}
\hline Treatment & $\begin{array}{l}\text { cAMP concentration } \\
\left(\mathrm{pmol} / 5 \cdot 10^{6} \text { cells }\right)\end{array}$ & $\%$ increase & $P$ value \\
\hline None & $4.01 \pm 0.07$ & - & - \\
\hline 15-Methyl-PGE $1(1.0 \mu \mathrm{M})$ & $5.15 \pm 0.25$ & 28.4 & $<0.05$ \\
\hline 15-Methyl-PGE $(10 \mu \mathrm{M})$ & $7.79 \pm 0.32$ & 94.0 & $<0.001$ \\
\hline 15-Methyl-PGE $(100 \mu \mathrm{M})$ & $7.47 \pm 0.97$ & 86.2 & $<0.05$ \\
\hline Theophylline $\left(5 \cdot 10^{-4} \mathrm{M}\right)$ & $4.80 \pm 0.06$ & 19.7 & $<0.02$ \\
\hline
\end{tabular}

Effects of 15-metyl-PGE $E_{1}$ on phorbol-myristateacetate-induced responses

In contrast to the inhibitory effects of 15 methyl-PGE 1 on f-Met-Leu-Phe-induced neutrophil responses, no inhibition of phorbol-myristate-acetate-induced membrane potential changes (Table II) and $\mathrm{O}_{2}^{-}$production (Table IV) were observed over a range of doses of stimulus. These studies indicate a stimulus-specific inhibitory effect of 15-methyl-PGE ${ }_{1}$ on the stimulated neutrophil fluorescence changes of $\mathrm{di}(\mathrm{S})-\mathrm{C}_{3}-(5)$-treated rat neutrophils and $\mathrm{O}_{2}^{-}$production.

\section{Discussion}

Prostaglandins of the $\mathrm{E}$ series and $\mathrm{PGI}_{2}$ have been shown to inhibit the production of $\mathrm{O}_{2}^{-}$, chemotaxis and secretion of lysosomal enzymes by neutrophils in response to a variety of stimuli, including f-Met-Leu-Phe [7-12]. However, there is a paucity of data examining the effect of prostaglandins on the early biochemical and biophysical events associated with stimulus-response coupling in the neutrophil. The data presented here demonstrate an inhibitory effect of 15-methyl$\mathrm{PGE}_{1}$ and $\mathrm{PGI}_{2}$ on f-Met-Leu-Phe-induced membrane potential changes of rat neutrophils. This is correlated with the inhibitory effects of 15-methyl$\mathrm{PGE}_{1}, \mathrm{PGI}_{2}$ and other agents known to increase intracellular cAMP levels on f-Met-Leu-Phestimulated $\mathrm{O}_{2}^{-}$production and lysosomal enzyme secretion. Other authors have demonstrated inhibitory effects of PGEs, $\mathrm{PGI}_{2}$ and cAMP agonists on neutrophil functional responses in a variety of species [7-12]. This study correlates the inhibitory effects of these agents with their ability to inhibit one of the early events associated with stimulus-response coupling in the neutrophil, i.e., changes in cell transmembrane potential.

Recently, Seligman et al. [21] observed a similar inhibition by histamine of f-Met-Leu-Phe-induced changes in transmembrane potential in human neutrophils. This inhibitory effect by histamine was correlated with its ability to inhibit f-MetLeu-Phe-induced functional responses of human neutrophils and was blocked by $\mathrm{H}_{1}$ receptor antagonist. Histamine has been shown by other authors to activate neutrophil-adenylate cyclase and increase intracellular cAMP levels [22]. Therefore, similar mechanisms of inhibition of transmembrane potential may underlie the inhibitory effect of histamine, PGEs and $\mathrm{PGI}_{2}$. This possibility is supported by the close correlation between intracellular 'cAMP elevation and inhibition of membrane potential changes.

In contrast to the inhibitory effects of 15methyl-PGE 1 on f-Met-Leu-Phe-induced $\mathrm{O}_{2}^{-}$production and changes in membrane potential, 15 methyl-PGE 1 did not inhibit either phorbol myristate acetate induced membrane potential changes or $\mathrm{O}_{2}^{-}$production. These observations further clarify the metabolic events associated with stimulus-response coupling in the neutrophil. Several laboratories have described distinct specific receptors for binding of f-Met-Leu-Phe and phorbol myristate acetate to neutrophils [17,24-27]. After 
binding of f-Met-Leu-Phe to the formyl peptide receptor on the neutrophil, a complex series of events occurs. One of the earliest events includes changes in $\mathrm{Na}^{+}, \mathrm{K}^{+}$and $\mathrm{Ca}^{2+}$ fluxes across the cell membrane and changes in transmembrane potential $[1-3,28,29]$. These changes in transmembrane potential can be monitored by changes in the fluorescence intensity of a variety of cyanine dyes, including di(S)- $\mathrm{C}_{3}-(5)$. Subsequent to changes in ion fluxes and transmembrane potential is the expression of the functional responses of the neutrophil, including $\mathrm{O}_{2}^{-}$production. Since neither 15-methyl-PGE 1 nor dibutyryl cAMP altered phorbol-myristate-acetate-induced neutrophil responses, it would appear that the primary inhibitory effect of prostaglandins and cAMP on f-MetLeu-Phe-stimulated cells is at a step or steps prior to activation of those processes involved in effecting changes in transmembrane potential, which are common to both f-Met-Leu-Phe and phorbol myristate acetate stimulation.

Two mechanisms for the inhibition of inflammatory cell activation by prostaglandins and cAMP have been proposed. Studies performed using mast cells and basophil leukemia cell lines suggest that prostaglandins and adenylate cyclase agonists increase cAMP levels and inhibit cell membrane-associated phospholipid transmethylation reactions that occur subsequent to cell stimulation and prior to calcium release and degranulation [13]. If similar mechanisms occur in f-MetLeu-Phe-stimulated neutrophils, our data would suggest that phorphol myristate acetate stimulation of neutrophils does not require phospholipid transmethylation reactions for changes in membrane potiential and functional responses to occur, and/or the methyltransferase activities associated with phorbol myristate acetate activation of human neutrophils are not regulated by prostaglandins and cAMP.

The second proposed mechanism for the inhibitory activity of prostaglandins as mediated via cAMP is that these agents alter the availability of intracellular free calcium. Studies performed using platelets in which transmethylation reactions do not appear to be a requirement for biological activity [30] indicate that $\mathrm{PGI}_{2}$ and increased intracellular cAMP levels decrease intracellular free-calcium levels after stimulation $[14,15]$. The data suggest that increased cAMP levels activate a calcium-dependent ATPase with increased sequestration of free calcium in the dense tubular system. Stimulation of rabbit and human neutrophils with f-Met-Leu-Phe causes a rapid increase in free intracellular calcium, as determined using the calcium-sensitive fluorescent probe quin-2 [31]. This increase in intracellular calcium correlates with the ability of f-Met-Leu-Phe to induce neutrophil degranulation and $\mathrm{O}_{2}^{-}$production. In addition, pretreatment of neutrophils with the intracellular calcium antagonist, 8-( $N, N$-diethylamino)octyl-3,4,5-trimethoxybenzoate also inhibits f-Met-Leu-Phe-induced $\mathrm{O}_{2}^{-}$production [32]. Thus, there is an abundance of data supporting the importance of intracellular calcium for stimulusresponse coupling in the neutrophil. However, the role of intracellular free calcium as a second messenger associated with phorbol myristate acetate stimulation of neutrophils is less clear. Although 8-( $N, N$-diethylamino)octyl-3,4,5-trimethoxybenzoate inhibits phorbol-myristate-acetate-induced neutrophil $\mathrm{O}_{2}^{-}$production [33], experiments by Sha'afi et al. [31], using quin-2, failed to demonstrate a rise in the level of free intracellular calcium with phorbol myristate acetate stimulation. This latter observation may explain the differential affects of prostaglandins on f-Met-Leu-Phe and phorbol-myristate-acetate-induced $\mathrm{O}_{2}^{-}$production. The data support the hypothesis that prostaglandins and cAMP modulate intracellular free calcium levels as their primary mechanism of inhibiting neutrophil biologic responses.

Additional effects of prostaglandins on cell membranes have been described. Kury et al. [34] observed increased deformability of $\mathrm{PGE}_{1}$-treated red blood cells and correlated these changes with a decrease in orientational relaxation times of fatty acid spin-labeled erythrocytes. They concluded that the fatty acid side chains in cell membrane phospholipids are more liquid or fluid in the presence of $\mathrm{PGE}_{1}$. Therefore, it is possible that the inhibitory activity of $15-$ methyl-PGE $_{1}$ and $\mathrm{PGI}_{2}$ toward neutrophils are in part secondary to direct alterations of the neutrophil plasma membrane's physicochemical properties. Three recent studies have described alterations in ligand-receptor interactions in prostaglandin treated platelets [35], macrophages [36] and neutrophils [16]. Of particular 
interest is the observation that neutrophils isolated from rats treated with 15 -methyl-PGE 1 show decreased lysosomal enzyme release and $\mathrm{O}_{2}^{-}$production in response to f-Met-Leu-Phe stimulation [16]. This is associated with a 2- to 3-fold decrease in binding affinity of f-Met-Leu-Phe to the formyl peptide receptor on these cells. Alterations in fMet-Leu-Phe receptor interactions may explain the ability of PGEs and cAMP to inhibit membrane potential changes associated with cell stimulation. Additional studies to examine the specificity of $\mathrm{PGE}_{1}$ and $\mathrm{cAMP}$ modulation of neutrophil ligand receptor interactions in vitro are currently in progress. Although the use of cyanine dyes as indicators of changes in transmembrane potential is an indirect technique for studying electrical potential across cell membranes, several authors have demonstrated a high degree of correlation of stimulusinduced fluorescence changes with other indices of cell activation, suggesting that this technique is indeed a valid measure for examining membrane potential changes [1-3]. The relative contributions of plasmalemmal or intracellular organelle membrane potential changes to the changes in fluorescence intensity of cyanine dyes has been discussed in the recent literature [3,37]. Although it is difficult to exclude the possibility that changes of mitochondrial membrane potentials contribute to the observed fluorescence changes associated with f-Met-Leu-Phe stimulation, it would appear that under our experimental conditions the observed changes in fluorescence of $\mathrm{di}(\mathrm{S})-\mathrm{C}_{3}$-(5)-labeled cells most likely represent changes in plasmalemmal membrane potentials.

In summary, our data indicate that 15-methyl$\mathrm{PGE}_{1}$ and $\mathrm{PGI}_{2}$ inhibit in a dose-dependent manner f-Met-Leu-Phe-induced transmembrane potential changes and functional responses of rat neutrophils. The lack of inhibiting effects of these agents on phorbol-myristate-acetate-induced membrane potential changes and superoxide-anion production suggest that this stimulus does not require the prostaglandin-sensitive step(s) to induce these cellular responses. The results confirm previous observations suggesting a close association, if not tight coupling, between transmembrane potential changes and the functional responses of the neutrophil.

\section{Acknowledgements}

This study was supported in part by grants from the National Institutes of Health HL-00905, HL-23192 and HL-28737.

\section{References}

1 Whitin, J.C., Chapman, C.E., Simons, E.R., Chovaniec, M.E. and Cohen, H.J. (1980) J. Biol. Chem. 255, 1874-1878

2 Seligmann, B.E., Gallin, E.K., Martin, D.L., Shair, W. and Gallin, J.I. (1980) J. Membrane Biol. 52, 257-272

3 Duque, R.E., Phan, S.H., Sulavik, M.C. and Ward, P.A. (1983) J. Biol. Chem. 258, 8123-8128

4 Kunkel, S.L., Thrall, R.T., Kunkel, R.G., Ward, P.A. and Zurier, R.B. (1979) J. Clin. Invest. 64, 1525-1528.

5 Fantone, J.C., Weingarten, B. and Kunkel, S.L. (1982) Biochem. Pharm. 31, 3126-3128

6 Zurier, R.B. and Quagliata, F. (1971) Nature 234, 304-306

7 Rivkin, I., Rosenblatt, J. and Becker, E.L. (1975) J. Immunol. 115, 1126-1134

8 O'Flaherty, J.T., Kreutzer, D.L. and Ward, P.A. (1979) Prostaglandins 17, 201-210

9 Fantone, J.C. and Kinnes, D.A. (1983) Biochem. Biophys. Res. Commun. 113, 506-512

10 Sedgwick, J.B., Berube, M.C. and Zurier, R.B. (1983) Fed. Proc. (420A).

11 Wong, K. and Freund, K. (1981) Can. J. Phys. Pharm. 59, 915-920

12 Zurier, R.B., Weissmann, G., Hoffstein, S., Kammerman, S. and Tai, H.H. (1974) J. Clin. Invest. 53, 297-309

13 Ishizaka, T., Hirata, F., Ishizaka, K. and Axelrod, J. (1980) Proc. Natl. Acad. Sci. U.S.A. 77, 1903-1906

14 Feinstein, M.D., Egan, J.J., Sha'afi, R.I. and White, J. (1983) Biochem. Biophys. Res. Commun. 113, 598-604

15 Kaser-Glansmen, R., Jakavobe, M., Georger, J. and Lusetter, E.F. (1979) Biochim. Biophys. Acta 466, 429-440.

16 Fantone, J.C., Marasco, W.A., Elgas, L.J. and Ward, P.A. (1983) J. Immunol. 130, 1495-1497

17 Showell, H.J., Freer, R.J., Zigmond, S.H., Schiffman, E., Aswanikumar, S., Corcoran, B. and Becker, E.L. (1976) J. Exp. Med. 143, 1154-1169

18 Woollen, J.W., Heyworth, R. and Walker, P.G. (1961) Biochem. J. 78, 111-119

19 Freedman, J.C. and Laris, P.C. (1980) Int. Rev. Cytol. Suppl. 12, 177-236

20 Utsumi, K., Sugiyama, K., Miyahara, N.M., Owai, M. and Inore, M. (1977) Cell. Struct. Funct. 2, 203-209

21 Seligmann, B.E., Fletcher, M.P. and Gallin, J.T. (1983) J. Immunol. 130, 1902-1909

22 Anderson, R., Glover, A. and Robson, A.R. (1977) J. Immunol. 118, 1690-1698

23 Kitagawa, S., Takaku, F. and Sakamoto, S. (1980) J. Clin. Invest. $65,74-81$

24 Schiffman, E., Corcoran, B. and Wahl, J.M. (1975) Proc. Natl. Acad. Sci. U.S.A. 72, 1059-1062 
25 Marasco, W.A., Showell, H.J., Freer, R.J. and Becker, E.L. (1982) J. Immunol. 128, 956-962

26 Lehrer, R.I. and Cohen, L. (1981) J. Clin. Invest. 68, 1314-1320

27 Goodwin, B.J. and Weinberg, J.B. (1982) J. Clin. Invest. 70, 699-706

28 Naccache, P.H., Showell, H.J., becker, E.L. and Sha'afi, R.I. (1979) J. Cell Biol. 83, 179-186

29 Naccache, P.H., Showell, H.J., Becker, E.L. and Sha'afi, R.I. (1977) J. Cell Biol. 75, 635-649

30 Shattil, S.J., Montgomery, J.A. and Chiang, P.K. (1982) Blood 59, 906-912

31 Sha'afi, R.I., White, J.R., Molski, R.F.P., Shefcyk, J., Volpi, M., Naccache, P.H. and Feinstein, M.B. (1983) Biochem. Biophys. Res. Commun. 114, 638-645
32 Becker, E.L., Showell, H.J., Naccache, P.H. and Sha'afi, R. (1981) Biochemistry of Acute Allergic Reactions, pp. 257-278, Alan Liss, New York

33 Smith, R.J. and Iden, J.J. (1979) Biochem. Biophys. Res. Commun. 91, 263-271

34 Kury, P.G., Ramwell, P.W. and McConnell, H.M. (1974) Biochem. Biophys. Res. Commun. 56, 478-483

35 Bennett, J.S., Vilaire, G. and Burch, F.W. (1981) J. Clin. Invest. 68, 981-989

36 Razin, E. and Globerson, A. (1979) Adv. Exp. Med Biol. $114,415-422$

37 Korchak, H.M., Rich, A.M., Wilkenfeld, C., Rutherford, L.E. and Weissmann, G. (1982) Biochem. Biophys. Res. Commun. 108, 1495-1501 